\title{
Karakteristik Fisik, Kandungan Gizi Tepung Kulit Pisang dan Perbandingannya terhadap Syarat Mutu Tepung Terigu
}

\section{Physical Characteristics, Nutritional Content of Banana Peel Flour and Its Comparison to Quality Requirement of Wheat Flour}

\author{
Titin Aryani1 ${ }^{*}$, Isnin Aulia Ulfah Mu'awanah ${ }^{2}$, Aji BAgus Widyantara ${ }^{3}$ \\ 1,2,3) Program Studi Teknologi Laboratorium Medis, Fakultas Ilmu Kesehatan \\ Universitas 'Aisyiyah Yogyakarta \\ Jl. Ringroad Barat, No.63, Mlangi, Nogotirto, Gamping, Sleman, Yogyakarta \\ *email : titinaryanipurnama@gmail.com
}

\begin{abstract}
ABSTRAK
Histori Artikel:

Dewasa ini, pangan fungsional merupakan hal yang banyak diperbincangkan. Alternatif sumber pangan berbahan dasar lokal merupakan suatu prioritas. Diantara berbagai jenis pangan fungsional,

Diajukan:

$04 / 08 / 2018$

Diterima:

$26 / 10 / 2018$

Diterbitkan:

$17 / 11 / 2018$ substituen tepung seperti tepung kulit pisang merupakan salah satu topik yang menarik karena kebutuhan masyarakat akan tepung terigu merupakan kebutuhan yang tak bisa terhindarkan. Penelitian ini bertujuan melakukan studi literature karakteristik fisik dan kandungan gizi pada berbagai jenis tepung kulit pisang. Metode penelitian ini adalah penelitian studi literatur dengan mencari referensi penelitian yang relevan dengan karakteristik fisik, kimia dan kandungan gizi berbagai jenis tepung kulit pisang. Sumber data yang digunakan berasal dari Google Scholar. Jenis data yang digunakan dalam penelitian ini adalah data sekunder yaitu data yang diperoleh dari laporan hasil penelitian, artikel jurnal, buku dan media elektronik. Hasil studi literatur menunjukkan secara umum, karakteristik tepung kulit pisang adalah berbentuk serbuk, berbau normal (khas pisang), memiliki rasa dekit getir dan berwarna coklat. Sedangkan, kandungan gizi tepung kulit pisang pada umumnya adalah mengandung karbohidrat, lemak, protein, air, abu, karoten, dan antosianin. Secara fitokimia, tepung kulit pisang juga memiliki aktivitas antioksidan yang cukup tinggi. Kesimpulan dari studi ini adalah tepung kulit pisang merupakan substituen tepung yang memiliki kandungan gizi memadai dengan karakter yang relatif baik jika digunakan sebagai pengganti tepung terigu.
\end{abstract}

Kata kunci: tepung, kulit pisang, karakteristik fisik, gizi

\begin{abstract}
Today, functional food is a matter of much discussion. Alternative sources of locally based food are a priority. Among the various types of functional food, flour substituent such as banana peel flour is one of the interesting topics because the community's need for wheat flour is an unavoidable necessity. This study aims to study literature physical characteristics and nutritional content of various types of banana peel flour. This research method is a literature study by looking for research references that are relevant to the physical, chemical and nutritional characteristics of various types of banana peel flour. The data source used is from Google Scholar. The type of data used in this study is secondary data, namely data obtained from research report, journal articles, books and electronic media. The results of literature studies show in general, the characteristics of banana peel flour is shaped powder, smells normal (typical banana), has a bitter taste and brown color. Meanwhile, the nutritional content of banana peel flour in general is contains carbohydrates, fats, proteins, water, ash, carotene, and anthocyanin. Phytochemically, banana peel flour also has high antioxidant activity. The conclusion of this study is banana peel flour is a substituent flour which has adequate nutritional content with relatively good character if used as a substitute for wheat flour.
\end{abstract}

Keywords: flour, banana peel, physical characteristics, nutrition 


\section{PENDAHULUAN}

Buah pisang merupakan makanan yang banyak dikonsumsi masyarakat karena dikenal sebagai salah satu sumber gizi dan sumber antioksidan yang bermanfaat sebagai penangkal radikal bebas. Pisang (Musa, sp.) merupakan salah satu komoditas buah yang dapat dibudidayakan di seluruh daerah tropis, termasuk Indonesia. Pemanfaatan pisang selain dikonsumsi langsung setelah pisang masak, juga dapat diolah menjadi aneka pangan, seperti dodol pisang, keripik pisang, dan lainlain. Penelitian dari Emaga et al. (2007) menyatakan bahwa kulit pisang mengandung serat pangan dalam jumlah $50 \mathrm{~g} / 100 \mathrm{~g}$, sehingga merupakan sumber serat pangan potensial.

Namun, meskipun pisang memiliki banyak manfaat, konsumsi pisang akan menyisakan limbah organik yaitu kulit pisang. Dengan demikian, diperlukan pengolahan kulit pisang agar menjadi produk yang lebih bermanfaat sehingga nilai guna pisang akan bertambah. Dalam penelitian Sukriyadi (2010), menyatakan bahwa semua jenis kulit pisang dapat diolah menjadi tepung, namun yang terbaik adalah kulit pisang raja karena memiliki struktur serat yang lebih tebal dan memiliki kandungan pati dan kalsium yang cukup tinggi. Sebagai substituen tepung, serat pangan yang terdapat didalamnya dapat memberikan efek fisiologis, seperti penyakit cardiovascular, konstipasi, iritas usus, kanker usus dan diabetes (Rodriguez et al., 2006). Serat pangan yang bersumber dari buah-buahan memiliki kualitas yang lebih baik daripada sumber serat lainnya, karena kandungan serat larut yang tinggi, serta kandungan asam fitat dan nilai kalori-nya rendah. Menurut Cho dan Samuel (2009), serat (seperti serat yang terapat dalam buah pisang) memiliki banyak manfaat termasuk dapat meningkatkan kesehatan pencernaan dan menurunkan berat badan serta mengatur kadar gula dalam darah dan mencegah diabetes tipe 2 .

Tepung terigu merupakan salah satu bahan pangan impor yang banyak dibutuhkan oleh masyarakat Indonesia. Tepung terigu dapat diolah menjadi banyak produk, antara lain mie, roti, kue, donat, dan berbagai aneka produk makanan kecil. Industri makanan berbahan baku tepung terigu berkembang sangat pesat di Indonesia, hal ini menyebabkan meningkatnya impor tepung terigu dari tahun ke tahun. Pemanfaatan kulit pisang sebagai substituen tepung terigu diharapkan dapat mengurangi impor tepung terigu.

Kandungan fitokimia seperti halnya antioksidan adalah senyawa non-gizi yang terdapat dalam tanaman yang dapat melindungi diri dari penyakit atau memiliki sifat pelindung dari penyakit. Berdasarkan manfaat dan potensi tersebut mengindikasikan bahwakandungan serat pangan yang tinggi pada kulit pisang memungkinkan pemanfaatan sifat fungsional kulit pisang dalam pembuatan produk kaya pati seperti tepung.

\section{METODE PENELITIAN}

\section{A. Jenis Penelitian}

Penelitian ini termasuk jenis penelitian studi literatur dengan mencari referensi penelitian yang relevan dengan karakteristik fisik, kandungan gizi pada berbagai jenis tepung kulit pisan dan perbandingannya dengan syarat mutu tepung terigu. Referensi penelitian yang diperoleh dari studi literatur dijadikan sebagai dasar dalam mendeskripsikan fakta-fakta terkait.

\section{B. Metode Pengumpulan Data}

Jenis data yang digunakan dalam penelitian ini adalah data primer dengan melakukan obervasi dan data sekunder yaitu data yang diperoleh dari artikel jurnal, buku dan media elektronik. Data-data yang sudah diperoleh kemudian dianalisis dengan metode analisis deskriptif. Dokumentasi merupakan metode untuk mencari dokumen atau data-data yang dianggap penting melalui artikel, jurnal, koran, buku, dan media elektronik yang berkaitan dengan karakteristik fisik dan kandungan gizi pada berbagai jenis tepung kulit pisang.

\section{HASIL DAN PEMBAHASAN}

\section{A. Karakteristik Fisik Tepung Kulit Pisang}

Karakteristik fisik tepung kulit pisang merupakan tampilan fisik tepung kulit pisang yang dapat diamati menggunakan pancaindera. Karakteristrik tepung kulit pisang ditampilkan pada Tabel 1. 
Tabel 1. Karakteristik Fisik Tepung Kulit Pisang

\begin{tabular}{llccccc}
\hline No. & Parameter & \multicolumn{5}{c}{ Hasil Uji Karakteristik Tepung Kulit Pisang } \\
\cline { 3 - 6 } & & Kepok $^{\mathrm{a}}$ & Uli $^{\mathrm{a}}$ & Raja $^{\mathrm{a}}$ & Raja $^{\mathrm{b}}$ & Raja $^{\mathrm{c}}$ \\
\hline 1. & Bentuk & Serbuk & Serbuk & Serbuk & Serbuk & Serbuk \\
2. & Bau & Normal & Normal & Normal & Normal & - \\
3. & Rasa & - & - & - & Sedikit getir & - \\
4. & Warna & Coklat & Coklat & Coklat & Coklat & - \\
\hline
\end{tabular}

Sumber: aDjunaedi (2006), ${ }^{\mathrm{b}}$ Aryani, dkk (2018), ' Syahruddin (2015)

Data pada Tabel 1 menunjukkan bahwa secara umum, hasil penelitian Djunaedi (2006), Aryani, dkk (2018) dan Syahruddin (2015) menunjukkan persamaan hasil. Dari ketiga penelitian tersebut menyatakan bahwa bentuk tepung kulit pisang secara umum adalah serbuk, bau tepung kulit pisang adalah normal, rasa tepung kulit pisang adalah getir dan warna tepung kulit pisang adalah coklat.

Bentuk serbuk merupakan bentuk umum tepung sehingga setiap bahan baku tepung diolah sedemikian rupa hingga mendapatkan bentuk serbuk. Menurut PKKP BKP (2011) pembuatan tepung kulit pisang dimulai dengan cara memotong kulit pisang kecil-kecil dengan ukuran kurang lebih $1 \mathrm{~cm} \mathrm{x}$ $0,5 \mathrm{~cm}$ dengan pisau atau alat pengiris. Kemudian merendam kulit pisang dalam larutan natrium tiosulfat dan garam selama 1 jam, setelah itu ditiriskan. Proses pengolahan tepung kulit buah dimulai dari pengeringan kulit menggunakan oven $60^{\circ} \mathrm{C}$ sampai kulit menjadi benar-benar kering sehingga hasil akhir yang didapat berupa tepung yang kering. Setelah kering atau kadar air kurang lebih 14 persen, potongan kulit buah dapat digiling/dihancurkan dengan menggunakan hammer mill atau ditumbuk. Hasil penggilingan kemudian diayak. Tepung kulit buah yang lolos dari ayakan dikemas dalam kantong plastik.

Karakter bau tepung kulit pisang adalah normal. Normal yang dimaksud merupakan bau normal khas pisang (Aryani, 2018). Artinya, bau normal yang diperoleh pada pembuatan tepung kulit pisang tidak seperti bau normal tepung terigu. Hal ini karena karakteristik bau tepung kulit merupakan identitas dari tepung. Disamping itu, proses pengolahan tepung kulit pisang yang dilakukan mampu menyimpan aroma khas dari pisang, sehingga menghasilkan aroma pisang pada tepung kulit pisang yang dihasilkan.

Karakter rasa tepung kulit pisang hanya dilaporkan oleh penelitian Aryani (2018), bahwa karakter rasa tepung kulit pisang adalah sedikit getir. Hal tersebut mungkin disebabkan oleh kandungan fitokimia seperti saponin yang terdapat dalam kulit pisang. Menurut Sirait (2007) Rasa saponin adalah pahit atau getir. Saponin bila dikocok akan membuih. Kemampuan menurunkan tegangan permukaan ini disebabkan molekul saponin terdiri dari hidrofor dan hidrofil. Bagian hidrofob adalah aglikonnya, bagian hidrofil adalah glikonnya. Sebagian besar saponin bereaksi netral (larut dalam air), beberapa ada yang bereaksi asam (sukar larut dalam air), sebagian kecil ada yang bereaksi basa. Aglikon saponin disebut sapogenin. Sapogenin sukar larut dalam air. Saponin dapat berupa senyawa yang mempunyai satu rantai gula atau dua rantai gula yang sebagian besar bercabang.

Karakter warna tepung kulit pisang pada semua hasil penelitian menunjukkan bahwa warna tepung kulit pisang adalah coklat. Warna coklat yang dihasilkan dari tepung kulit pisang merupakan efek dari reaksi browning. Hal ini disebabkan oksidasi dengan udara sehingga terbentuk reaksi pencokelatan oleh pengaruh enzim yang terdapat dalam bahan pangan tersebut (browning enzymatic). Pencokelatan karena enzim merupakan reaksi antara oksigen dan suatu senyawa fenol yang dikatalisis oleh polifenol oksidase. Pembentukan warna coklat pada kulit pisang dipicu oleh reaksi oksidasi yang dikatalisis oleh enzim fenol oksidase atau polifenol oksidase. Enzim tersebut dapat mengkatalis oksidasi senyawa fenol menjadi quinon dan kemudian dipolimerasi menjadi pigmen melaniadin yang berwarna coklat (Mardiah, 1996).

\section{B. Kandungan Gizi Tepung Kulit Pisang}

Hasil studi literatur diperoleh hasil analisis kadar air, abu, lemak, protein, karbohidrat, serat kalsium dan fosfor pada berbagai jenis tepung kulit pisang yang ditampilkan pada Tabel 2. 
Tabel 2. Data Hasil Analisis Gizi Tepung Kulit Pisang

\begin{tabular}{|c|c|c|c|c|c|c|c|c|c|c|}
\hline \multirow{2}{*}{$\begin{array}{l}\text { Parameter } \\
\text { Zat Gizi (\%) }\end{array}$} & \multicolumn{9}{|c|}{ Hasil Analisis Tepung Kulit Pisang } & \multirow{2}{*}{$\begin{array}{l}\text { Rata- } \\
\text { rata }\end{array}$} \\
\hline & Kepok $^{a}$ & Ulia & Raja $^{a}$ & Rajab $^{b}$ & Rajac $^{c}$ & Tanduk $^{\mathrm{d}}$ & Nangkad & Kepok $^{d}$ & Ulie & \\
\hline Kadar Air & 2,05 & 1,96 & 3,93 & 6,92 & 13,63 & 7,34 & 7,26 & 7,41 & 9,02 & 6,61 \\
\hline Lemak & 4,40 & 4,58 & 4,26 & 2,83 & 12,71 & 6,34 & 5,83 & 15,29 & 1,18 & 6,37 \\
\hline Protein & 9,86 & 9,25 & 8,51 & 5,32 & 5,15 & 7,54 & 6,94 & 5,15 & 6,76 & 7,16 \\
\hline Karbohidrat & 82,59 & 82,7 & 83,31 & 73,98 & 58,43 & - & - & - & - & 76,20 \\
\hline Serat & 32,73 & 32,58 & 40,34 & 40,76 & - & - & - & - & - & 36,60 \\
\hline Kalsium & 0,83 & - & 0,21 & - & - & 0,23 & 0,26 & 0,23 & 0,65 & 0,34 \\
\hline Fosfor & - & - & - & - & - & 0,18 & 0,23 & 0,22 & 0,44 & 0,26 \\
\hline Karoten & - & - & - & 0,14 & - & - & - & - & - & 0,13 \\
\hline Antosianin & - & - & - & 15,61 & - & - & - & - & - & 15,61 \\
\hline
\end{tabular}

Sumber: aDjunaedi (2006), bAryani, dkk (2018), 'Syahruddin (2015), dHernawati dan Ariyani (2007), eZahera (2012)

Berdasarkan hasil studi literatur diperoleh informasi bahwa rata-rata tepung kulit pisang memiliki kandungan gizi yaitu, kadar air sebanyak 6,61, abu 1,10, lemak 6,37, protein 7,16 , karbohidrat 76,20 , serat 36,60 , kalsium 0,34, fosfor 0,26, karoten 0,14, dan antosianin 15,61 \%. Hasil studi literatur menunjukkan kadar gizi tertinggi pada tepung kulit pisang berdasarkan parameter zat gizi pada Tabel 2 diatas adalah kandungan karbohidrat (76,20\%). Sedangkan kadar gizi terendah pada tepung kulit pisang adalah fosfor (0,26\%). Menurut Fakhrizal dan Yuniar (2016) kulit pisang mengandung karbohidrat terutama bahan ekstrak tanpa nitrogen sebesar 66,20 \%.

Kandungan proksimat, yaitu air, abu, lemak, protein, karbohidrat dan serat pada tepung kulit pisang merupakan zat gizi makro yang terbanyak dalam kulit pisang. Pada setiap bahan pangan yang paling kering sekalipun, masih terdapat kandungan air walaupun dalam jumlah yang kecil (Defano, 2000). Protein, karbohidrat dan lemak merupakan komponen penting yang terdapat dalam makanan. Serat kasar terdiri dari selulosa, hemiselulosa dan lignin. Selulosa dan hemiselulosa merupakan komponen dinding sel tumbuhan dan tidak dapat dicerna oleh manusia. Adapun mineral yang umum terdapat pada kulit pisang adalah kalsium dan fosfor.

Karotenoid merupakan suatu zat alami yang sangat penting dan mempunyai sifat larut dalam lemak atau pelarut organik tetapi tidak larut dalam air yang merupakan suatu kelompok pigmen berwarna orange, merah atau kuning (Kurniawan, et al, 2010). Menurut Fakhrizal dan Yuniar (2016), kulit pisang memiliki kandungan vitamin A sangat tinggi, terutama provitamin A, yaitu beta-karoten, sebesar 45 mg per 100 gram berat kering. Betakaroten tersebut juga berperan sebagai antioksidan. Penelitian Zahera (2012) kulit pisang uli yang diolah menjadi tepung memiliki kandungan beta-karoten sebesar 5,127 $\mathrm{mg} / 100 \mathrm{~g}$.

Antosianin telah banyak digunakan sebagai pewarna, khususnya minuman, karena banyak pewarna sintetis diketahui bersifat toksik dan karsinogenik. Menurut Clifford et al. (2000), JEFCA (Joint FAO/WHO Expert Committee on Food Additives) telah menyatakan bahwa ekstrak yang mengandung antosianin efek toksisitasnya rendah. Selain berperan sebagai pewarna makanan, antosianin juga dipercaya berperan dalam sistem biologis, termasuk kemampuan sebagai pengikat radikal bebas (free radical scavenging), cardio protective capacity dan kemampuan untuk mengambat tahap inisiasi reaksi kimiawi yang menyebabkan karsinogenesis (Smith et al., 2000).

Antosianin dipercaya dapat memberikan manfaat bagi kesehatan manusia. Antosianin ini diketahui dapat diabsorbsi dalam bentuk molekul utuh dalam lambung (Passamonti et al., 2003), meskipun absorbsinya jauh dibawah $1 \%$, antosianin setelah ditransport ke tempat yang memiliki aktivitas metabolik tinggi memperlihatkan aktivitas sistemik seperti antineoplastik, antikarsinogenik, antiatherogenik, antiviral, dan efek anti inflammatory, menurunkan permeabilitas dan fragilitas kapiler dan penghambatan agregasi platelet serta immunitas, semua aktivitas ini didasarkan pada peranannya sebagai antioksidan (Clifford et al., 2000; Middleton et al., 2000). Antosianin yang tidak terabsorbsi memberikan perlindungan terhadap kanker kolon (Halliwell et al., 2000).

\section{Perbandingan Karakteristik Fisik dan Kandungan Gizi Tepung Kulit Pisang terhadap Syarat Mutu Tepung Terigu}


Standar Nasional Indonesia (SNI) adalah satu-satunya standar yang berlaku secara nasional di Indonesia. SNI dirumuskan oleh Panitia Teknis dan ditetapkan oleh Badan Standardisasi Nasional (BSN) (Wikipedia, 2018). Badan Standarisasi Nasional menetapkan 105 produk yang diwajibkan untuk memenuhi Standar Nasional Indonesia (SNI) untuk melindungi kepentingan umum, keamanan negara, perkembangan ekonomi nasional, dan pelestarian fungsi lingkungan hidup. Suatu produk yang sudah memenuhi SNI akan diberikan tanda SNI pada produknya. Apabila suatu produk tertentu telah diwajibkan SNI namun tidak memiliki tanda SNI, maka produk tersebut tidak boleh diedarkan atau diperdagangkan di wilayah Indonesia (Sari, 2015). Tepung terigu merupakan salah satu dari 105 produk yang wajib SNI. Perbandingan karakteristik fisik berbagai jenis tepung kulit pisang terhadap syarat mutu tepung terigu dalam SNI Tepung Terigu sebagai makanan (SNI 3751:2006) ditampilkan pada Tabel 3.

Tabel 3. Perbandingan Karakteristik Fisik dan Kandungan Gizi berbagai Jenis Tepung Kulit Pisang terhadap SNI Tepung Terigu sebagai Makanan (SNI 3751:2006)

\begin{tabular}{|c|c|c|c|c|c|c|c|}
\hline \multirow[t]{3}{*}{ No } & \multirow{2}{*}{\multicolumn{2}{|c|}{ Syarat Mutu Tepung Terigu }} & \multicolumn{4}{|c|}{ Hasil Analisa Tepung Kulit Pisang } & \multirow{3}{*}{$\begin{array}{l}\text { Raja } \\
\text { Hasil Ujic }\end{array}$} \\
\hline & & & Kepok & Uli & Raja & Raja & \\
\hline & Jenis Uji & Persyaratan & Hasil Ujia & Hasil Ujia & Hasil Ujia & Hasil Ujib & \\
\hline 1. & Bentuk & Serbuk & Serbuk & Serbuk & Serbuk & Serbuk & Serbuk \\
\hline 2. & $\mathrm{Bau}$ & Normal & Normal & Normal & Normal & Normal & - \\
\hline 3. & Warna & Putih & Coklat & Coklat & Coklat & Coklat & - \\
\hline 4. & Benda asing & Tidak ada & Tidak ada & Tidak ada & Tidak ada & Tidak ada & - \\
\hline 5. & Serangga & Tidak ada & Tidak ada & Tidak ada & Tidak ada & Tidak ada & - \\
\hline 6. & $\begin{array}{l}\text { Kehalusan } \\
(\%)\end{array}$ & 95 & - & - & - & - & - \\
\hline 7. & $\begin{array}{l}\text { Kadar Air } \\
(\mathrm{b} / \mathrm{b})(\%)\end{array}$ & Maks. 14,5 & 2,05 & 1,96 & 3,93 & 6,92 & 13,63 \\
\hline 8. & $\begin{array}{l}\text { Kadar Abu } \\
\text { (b/b) \% }\end{array}$ & Maks. 0,7 & 1,10 & 0,9 & 0,60 & 1,81 & - \\
\hline 9. & Lemak (\%) & - & 4,40 & 4,58 & 4,26 & 2,83 & 12,71 \\
\hline 10. & $\begin{array}{l}\text { Kadar } \\
\text { Protein (\%) }\end{array}$ & Min. 7,0 & 9,86 & 9,25 & 8,51 & 5,32 & 5,15 \\
\hline 11. & $\begin{array}{l}\text { Karbohidrat } \\
(\%)\end{array}$ & - & 82,59 & 82,7 & 83,31 & 73,98 & 58,43 \\
\hline 12. & Serat Pangan & - & 32,73 & 32,58 & 40,34 & 40,76 & 16,11 \\
\hline
\end{tabular}

Sumber: aDjunaedi (2006), ${ }^{b}$ Aryani, dkk (2018), cSyahruddin (2015)

Berdasarkan data pada Tabel 3, perbandingan karakteristik fisik dan kandungan gizi berbagai jenis tepung kulit pisang terhadap syarat mutu tepung terigu menunjukkan bahwa rata-rata tepung kulit pisang memenuhi uji persyaratan bentuk, bau, benda asing, kadar air, abu, lemak, karbohidrat dan serat pangan. Syarat mutu tepung terigu yang tidak terpenuhi adalah warna tepung kulit pisang. Untuk parameter protein, terdapat 2 penelitian yang menunjukkan kadar protein tepung kulit pisang yang tidak memenuhi syarat mutu tepung terigu yaitu pada penelitian Aryani, dkk (2018) dan Syahruddin (2015).

\section{KESIMPULAN}

Kesimpulan dari studi ini adalah tepung kulit pisang merupakan substituen tepung yang memiliki kandungan gizi memadai dengan karakter yang relatif baik jika digunakan sebagai pengganti tepung terigu karena terdapat banyak parameter yang memenuhi syarat mutu tepung terigu.

\section{UCAPAN TERIMAKASIH}

Penulis mengucapkan terima kasih kepada Kemenristek DIKTI yang telah mendanai penelitian sebelumnya yang terkait dengan tepung kulit pisang, sehingga dapat menjadi referensi pada artikel ini. 


\section{DAFTAR PUSTAKA}

Aryani, T. dkk. (2018). Efektivitas Pengolahan Limbah Kulit Pisang Menjadi Donat Ditunjau dari Analisis Fitokimia, Proksimat dan Organoleptik. Laporan Penelitian Hibah Penelitian Dosen Pemula DIKTI 2018 Universitas 'Aisyiyah Yogyakarta: Yogyakarta.

Cho, S.S., dan Samuel, P. (2009). Fiber Ingredients: Food Applications and Health Benefits, Florida: CRC Press.

Clifford, M. N. (2000). Anthocyanins-nature, occurrence and dietary burden. Journal of the Science of Food and Agriculture, 80, 1063-1072.

Defano. (2000). Ilmu Makanan Ternak. Fakultas Peternakan Universitas Gajah Mada, Yogyakarta: Gajah Mada University Press.

Djunaedi, E. (2006). Pemanfaatan Limbah Kulit Pisang Sebagai Sumber Pangan Alternatif dalam Pembuatan Cookies. Program Studi Kimia Fakultas Matematika dan Ilmu Pengetahuan Alam Universitas Pakuan.

Emaga, T.H. Andrianaivo, R.H. Wathelet, B. Tchango, J.T. and Paquot, M. (2007). Effects of the stage of Maturation and Varieties on the Chemical Composition of Banana and Plantain peels, Food Chemistry, 103, 590600.

Fakhrizal dan Yuniar. (2016). Kombinasi Tepung Kulit Pisang dan Tepung Kulit Ubi Terhadap Kecernaan Bahan Kering dan Bahan Organik pada Ayam Broiler. Jurnal Ilmiah Peternakan. 4 (2), 8-11.

Halliwell B, K Zhao \& M. Whiteman. (2000). The Gastrointestinal Tract: The Major Site of Antioxidant Action?. Free Radical Research, 33, 819-830.

Hernawati, H. dan Aryani, A. (2007). Potensi tepung kulit pisang sebagai pakan alternatif pada ransum ternak unggas. Laporan Penelitian Hibah Bersaing. Universitas Pendidikan Indonesia, Bandung.

Kurniawan, M. Izzati, M. Nurchayati,Y. (2010). Kandungan Klorofil, Karotenoid, dan Vitamin C pada Beberapa Spesies Tumbuhan Akautik. Buletin Anatomi dan Fisiologi, 18(1), 28-40.

Mardiah E. (1996). Penentuan aktivitas dan inhibisi enzim polifenol oksidase dari apel (Pyrus malus Linn.). Jurnal Kimia Andalas, 2(2).

Middleton, E. Kandaswami, C. \& Theoharides, T. C. (2000). The effects of plant flavonoids on mammalian cells:implications for inflammation, heart disease, and cancer. Pharmacological Reviews, 52, 673-751.

Passamonti, S. Vrhovsek, U. Vanzo, A \& Mattivi, F. (2003). The Stomach as a Site For Anthocyanins Absorption From Food. FEBS Letters, 544, 210-213.

PKKP BKP. (2011). Membuat Tepung dari Kulit Pisang. Pusat Penganekaragaman Konsumsi dan Kemanan Pangan Badan Ketahanan Pangan Republik Indonesia. Diakses pada 2 Mei 2018. http://pusatpkkp.bkp.pertanian.go.id/berita-205membuat-tepung-dari-kulit-pisang.html.

Rodriguez, R. Jimenez, A. Fernandez Bolanos, J. Guillen, R. \& Heredia, A. (2006). Dietary Fibre from Vegetable Products as Source of Functional Ingredients, Trends in Food Science and Technology, 17, 3-15.

Sari, D.N., (2015). Ini 105 Produk yang Wajib SNI, Diambil dari alamat website: http://industri.bisnis.com/read/2015111 9/257/493753/ini-105-produk-yangwajib-sni, Diakses pada 1 Mei 2018.

Sukriyadi, L. (2010). Kajian Sifat Kimia dan Sifat Organoleptik Pada Tepung Kulit Pisang Dari Beberapa Varietas Pisang, (Skripsi), Universitas Khairun Ternate): Ternate.

Syahruddin, A.N. dkk. (2015). Identifikasi Zat Gizi dan Kualitas Tepung Kulit Pisang Raja (Musa Sapientum) dengan Metode Pengeringan Sinar Matahari dan Oven, Media Pangan Indonesia, 19(1), 116-121.

Smith, M. K. Marley, D. Seigler, K. Singletary \& Meline, B. (2000). Bioactive Properties of Wild.

Sirait, M. (2007). Penuntun Fitokimia dalam Farmasi. Bandung: Penerbit ITB.

Zahera, R. (2012). Pemanfaatan Beta-Karoten dalam Tepung Kulit Pisang sebagai Pengganti Sebagian Jagung untuk Menghasilkan Telur Ayam Arab Rendah Kolesterol. Skripsi. Bogor : Departemen Ilmu Nutrisi dan Teknologi Pakan, Fakultas Peternakan, Institut Pertanian Bogor: Bogor.

Wikipedia. (2018). Standar Nasional Indonesia. https://id.wikipedia.org/wiki /Standar_Nasional_Indonesia. Diakses pada 21 Mei 2018. 